\title{
Some Morphological Features of Arbëresh, Distinguished Poem "Songs of Milosao" of Girolamo De Rada
}

\section{Doi:10.5901/mjss.2013.v4n3p601}

\author{
Monika Hasani
}

\begin{abstract}
The poem "Songs of Milosao" is important not only for its literary value, but also linguistic. Within verses of poetry finds the typical morphological features of idioms Arbëresh, merged with the efforts of a researcher as Girolamo de Rada with dedication and absolute responsibility to submit forms and expressions best Arbëresh the Italian language. So based on the research we have done in the study of morphological features work Arbëresh see the De Rada such as the dominance of structural elements and basic phonetics matched with Tosk dialect, where there exist verbal forms Gheg. Among the innovations typical idioms Arbëresh arising in the form of poem distinguish the present time the way indicative mood, which the De Rada in comparison to today's Albanian distinguished firstly, the reduction in the use of the suffix-th as verbal termination, which is a phenomenon developed after separation of the speech Arbëresh the parent trunk. Meanwhile the conservative grammatical forms which are stored in criminal distinguish itself forms the third time singular imperfect indicative mood way to ending Ney, who appears the same as the Chameria (which is considered as one of the most conservative dialects of the Albanian language). Given the poem "Songs of Milosao", we can say that Arbëresh discourses are coated with dialectal variety, divided into two main components: archaism and innovation.
\end{abstract}

Lyric-autobiographical novel "Songs of Milosao", given as the author himself says: "His Excellency, General, Demetrius Alexander, those songs are evidence that the approach to the ancient customs of Epirus lost land ", and inspired by a popular tear-jerking melodies:("Mos më garrosh, oi trim , assai uudh/" )"Do not lose yourself that way, O brave fellowl (Se saa të desha miir u nëng e dii")(How much did I love you,l'll never know)"1 it is important not only for its literary, but also for it's language, as you know, it is a poetic expression of the spirit of De Rada, where the poetic forms of the work and any particular part of it is taken by Albanian folk mix Arberesh songs, which he had begun to collect since in his youth. The above fact draws our attention linguistically, to distinguish his poetry in several morphological features of the Arberesh speech, merged with the efforts of a researcher as Jeronim de Rada with dedication and absolute responsibility to submit forms and expressions in the best way the Italian Arberesh language. So based on the research we have done in the study of the work we see these morphological features of Arberesh of De Rada:

1. Lack of admiralty way, which has not yet been crystallized, its expression achieved with other grammatical.

2. Composition of Arberesh discourse by two components: the fact that they brought with them from their native land and from that parent have created or received by the dialects in the host country. The components that have brought with them from the mother tongue, conservative distinguish grammatical forms such as forms of self-third time singular imperfect indicative mood way to ending -"ney", who appears the same as the Chameria (which is named regional dialect as one of the most conservative of the Albanian language): just like of "ruanej shkonej vasheza mespurtek" (cheke went the girl with thin waste goes )(Song VII), "nd'era tundënej vadhezit"(through wind she wasdancing) (Song VII) "Nje ere ngrënej pluhurin, shtëfrinej mureve (a win raised dusts nortwalls)((Song XVIII), mbi tufa pa ilit pare bukurith, çë dritësonej (on the clouds (she) saw the firs star illuminated), e jëma çë I qanej mb'anë(mother was crying aside)(songXIV), si një marmur me logaaz ruanej(maintained as a frozen marble) (song X), trimi ghipënej murgiarit (the brave ride the horse) (song IX), porsi ajo si kish zakon mëë së vinej Kroiri ( but she didn't go to the spring like she use to) (song IX), te ferri cë na fsheghnej ka udha (to the thorns who was hiding from the road)(song XI). Specific expression of shapes consisting of time going into the active, passive, which is located just in the dialect of Chameria and rarely the region of Kruja idioms and Shale of Bajgores e.g.(deljet tona u kinë gapur (ishin hapur) our sheep were opened song XIX, addition of (veç e mbannën një kumbull u kish uljur me trim ) holding under plum trees was sitting a brave fellow (Song XXII): suffixes of three people rest plural-jim,-sion-jin: bijim (= bënjim) bijin, bijin, similar to camërisht regional dialect maintaining a flame-the first person verbs with steadfast voice type, at: "u pushonj ndë kët dimër, më të shkonj kësaj udhe" (I rested all this winter, let me go this way ). This feature used by the this author of arberesh lecture is met also in the northern tosk dialect.

${ }^{1}$ De Rada, "Poesie Albanesi del Secolo XV. Canti Di Milosao Figlio del Despota di Scutari, Napoli 1836 
While we have found no difference in grammatical forms comparing with today's Albanian ..example, forms simple past tense "larg e pa u pataks mizoreja ( the girl looked way and got scared ), dielli ra tek shtrati(sun felon the bed), cë shkararti pesë ullinj (after shaking five olive trees )" with some differences that can be seen as storage once the most ancient forms such as non sigma tic aorist of verbs to be.tosee.to say (jam, shoh, them: (unë) qeva (ti) qeve; (unë) pe, (ti) pe; (unë) the, (ti) the) time as new personal developments, which that are obtained in this dialect after separation from the Albanian trunk. Such is the example aorist adding to the -ta endings instead of -va in those with the verbs with vowel (type: frit has sea).

The forms of the present simple the way of indicative mood, which the De Rada comparing to today's Albanian is distinguished primarily to the reduction in the use of the reductive suffix-the as verbal termination, which is a phenomenon developed after the separation of arberesh regional dialect from the Albanian trunk. De Rada although has not included this version in his grammar, he has widely used in his poetry work, except at the present simple of indicative mood, some other time this way. This variation in the present tense is used several times in his poetry work, mainly in the third person singular example :mbi shtrat na vemënith (will go to bed) (song V), cehren më i shuanith (blurs my face), gjumi mua më ljodhënith (sleep makes me tired)(songVIII), dielli që dihet vashës i qeshënith (the sun rises laugh to the girl), noerit më bienith (my minds spin around )(song XI), vera më e magjepsënith (summer fascinate me ) (song XXVI), shkon e jëma e klanith (mother goes crying)(song XXIII) bushtrën njerk së kanith (they don't have a bitch stepmother )(song XXVII). This phenomenon also occurs in other tenses of the indicative mood active voice as in the imperfect tense zgjidhëtith( choose) nga një tuf re, zilepsënith(jealous), kurmin t'im fiantaksënith (my body resemble) (song XI) in a simple past active voice (lot i ranith (the tears fell), kurmi i vet i qeshënith (his body was laughing ) (song XXII), in the past perfect tense ) ish dieghurith (was burning with thirst),atë kish gharruarith (he was forgotten)(song XXIX).

In general, the language used by De Rada, as all the regional Arberesh dialects, has structural elements and basic phonetics matched with Tosk dialect. As prof. Çabej has stated " The Albanian arberesh regional dialects of Italy are quite close to each other and their main features are as they tosk therefore entitled to be included in the Tosk dialect." But there exist Gheg verbal forms too. From the poem De Rada have encountered gerundive unmitigated form, as well, which has specially the particle by its "tue" version appeared, and as we find in today's geg dialect. Connected to the verbal component of this are noticed deviations form of the dialect vocabulary, without significant changes as the plane phonetic and semantic p.sh;" Por lumbardh e Anakreontit, mua më zgjoi tue fluturuar qelqeve finestrës (but anacreontic gull woke me flying through the window panels)(song I)

Më qëlonej tue fiantaksur (slept with dreaming), se përdore poshtë shkoim te shtëpitë e njerëzve ( in hand caught the go to people's homes) (song VI)

Gjumi mua më ljodhënith (lodh), ( the sleep is making me tired ) kurmi vette tue m'u reshtur ( si një gruaje që mbrëmje si largohet)( as a woman who leaves tonight)(song VI)

Oh, vasha kryegështenjë të vihej ture tieerr, gjysëm në terr e në dritë(if girl with brown hair to sit in the semidarkness sand spinning wool) (song VI)"

Taking "Songs of Milosao" as an example, we can say that Arberesh discourses are coated with the dialectal diversity in their morphological traits and have a mixed dialect that occurred after displacement of Arberesh people in Italy

According to researchers, most of them appear the same quotient regardless of each other and coincide with Tosk dialect. Frequently dialects of Arberesh at poetry work may occur in two or more views. They coincide with a part-time tosk dialect other times, but even with geg as well. There is a coincidence three limbs, which coincides with one part of toskerishtes language together and both conform to any of the geg dialect.

\section{References}

Çabej E., Story structure for the Albanian dialect, the "Albanian Dialectology", II, Tirana, 1974.Dialectology, reprint, Tirana 2009

De Padova, Linguistic survey of the San Marzano Arbëresh dialect, the "Albanian Dialectology", V, 1987, p. 372-713

Fortino I.C .Restorations in Arbëresh language, "Our Language", 3, 1984.

Kamsi K. Albanians in Italy, Phoenix, Shkodra, 2006.

Kastrati J. Jeronim de Rada, life and works, Tirana, 1980.

Kodra Z, Some linguistic notes collected in the villages of Calabria Arbëresh in "St. Fil.", 1, 1966, p. 139-149

Shkurtaj Gj., Arbëresh dialect Notes to the San Marzano, the "St. Fil.", 4, 1979, p. 113-141

Shkurtaj Gj., Look at the way verbal traits indicative mood of the speech Arbëresh the province of Cosenza, in "St. Fil.", 2, 1975, p. 71-87.

Solano F, Comments on Spoken Italian-Albanian "Shejzat", Rome, 1960, no. 3-4.

Solano F, Data dialects in the book " Manual of the Albanian language", Corigliano Calabro, 1972

Solano F, Manual of the Albanian language, Elements of morphology and syntax-Outline of dialects,Corigliano Calabro, 1972.

Solano F, The Albanian dialects of 'Southern Italy. I. Notes for a classification in"Quaderni Fire", Castrovillari, 1979.

Totoni M. Affiliation Arbëresh discourses of Italy in the structure of Albanian dialect, the "Fire", n. 27, anno XII, S. Demetri Corone, 1980. 